\title{
Territorializing the Indian Ocean: Transnational imaginaries and World-Literature in João Paulo Borges Coelho
}

\section{Gabriela B. Zanfelice*, Elena Brugioni.}

\begin{abstract}
This research project is situated in the fields of Indian Ocean Studies, Postcolonial Theory and World-Literature and aims at analysing the two short stories books Índicos Indícios I - Setentrião and Índicos Indícios II - Meridião (2005) by mozambican contemporary writer João Paulo Borges Coelho. The aim is to investigate to what degree the Indian Ocean, as a transnational geography and as an alternative critical paradigm, represents a substantial critical framework for the study of African Literatures on a global scale. Challenging the critical approaches grounded in spatial and linguistic perspectives, the Indian Ocean paradigm will be analyzed as a critical cartography through a theoretical articulation with the field the World-literary Studies. Addressing the theme of the sea as a critical framework with which rethink concepts of nation, territory, culture and identity in contemporary Mozambican literature, we aim for an articulation of the specificities of the Indian Ocean Studies with the theoretical discussion proposed by the Warwick Research Collective (WReC) about World-Literature and its tensions and potentialities for the study of João Paulo Borges Coelho.
\end{abstract}

\section{Key words:}

World-Literature, African Literatures, Indian Ocean Studies.

\section{Introduction}

The study of African Literatures is usually systematized through two predominant conceptualizations, based, for their most part, on territorial cartographies or linguistic definitions. The spatial paradigm, on the one hand, values literature only for its degree of rupture between colonial and postcolonial space and time" (Brugioni, 2013a, p. 11) and considers literary works as automatically attributable to the political nation. The linguistic paradigm, on the other hand, represents a colonialist approach where the reinforcement of European languages maintains a hegemony of the former empire over its former colonies, undermining all the other languages in the continent even though they are numerically dominant. From this framework we can attest the development of a field of studies geared to restricting a wide variety of texts to superficial homogenizations. This Project argues that both operational paradigms are symptomatic and fundamentally insufficient for the reading and placing of authors and texts whose writings suggest, in reality, a wide variety of differential imaginaries, posing key theoretical and epistemological questions concerning the cultural and institutional affirmation of the African Literatures. In contrast to these frameworks, this Research Project seeks to outline an operationalization of the Indian Ocean as an alternative critical paradigm for both the study of African Literatures and the field of Comparative Literatures through an analysis of the short story books Índicos Indícios I - Setentrião (2005a) and Índicos Indícios II - Meridião (2005b) by Mozambican author João Paulo Borges Coelho. The aim is to investigate to what degree the imaginaries built in Borges Coelho's narratives represent the theme of the sea as a substantial critical framework for the study of African Literatures on a global scale. Thus, calling on some of the topics and critical debates developed within the fields of Postcolonial Theory and, more recently, of World-
Literature, we intend to treat the Indian Ocean as a literary cartography whose operationalization challenges typical national and/or linguistic based approaches. We intend to think Mozambican's modernity and contemporaneity as a part of a global scale framework based on Postcolonial and World-literary Theories, regarding the Indian Ocean as a territory and as a fundamental critical cartography for the comprehension of Índicos Indícios narratives. Investigating the topics addressed in the books as an aesthetic and conceptual tool with which rethink the concepts of space, time, literature and modernity, we aim for an articulation of the specificities of the Indian Ocean Studies with the theoretical discussion proposed by the Warwick Research Collective (WREC, 2015) about WorldLiterature and its tensions and potentialities for the study of an author like João Paulo Borges Coelho. We argue that our understanding can provide novel tools and methodologies with which to read and problematize African Literatures in a comparative perspective.

\section{Acknowledgement}

Apoio à Pesquisa FAPESP (IC) Ref. 2018/20953-6

Borges Coelho, João Paulo. (2005a). Índicos Indícios: Setentrião. Lisboa: Caminho.

Borges Coelho, J. P. (2005b). Índicos Indícios: Meridião. Lisboa: Caminho. Brugioni, Elena (2013a). "Literary Cartographies and Humanistic Criticism. The Indian Ocean as a "critical paradigm"”. in Humanidades: Novos Paradigmas do Conhecimento e da Investigação, pp. 87-100.

WReC (2015). Combined and Uneven Development: Towards a New Theory of World-Literature. Liverpool: Liverpool University Press. 